\title{
Absorption of fat and calcium by low birthweight infants from milks containing butterfat and olive oil
}

\author{
DONALD BARLTROP and THOMAS E. OPPÉ \\ From the Paediatric Unit, St. Mary's Hospital Medical School, London
}

\begin{abstract}
Barltrop, D., and Oppé, T. E. (1973). Archives of Disease in Childhood, 48, 496. Absorption of fat and calcium by low birthweight infants from milks containing butterfat and olive oil. The absorption of fat and calcium from milks differing only in the nature of their principal lipid component has been determined in groups of premature infants. Infants receiving milk containing butterfat retained less fat than those receiving milk containing olive oil. No significant difference in the absorption of calcium was found, and this was not affected by age or maturation. The retention of calcium was not related to the efficiency of fat absorption but tended to increase with age.
\end{abstract}

Many attempts have been made to improve infant milk formulae based upon cow's milk, and increasing attention is being paid to the properties of milk fat (Williams et al., 1970). Butterfat is poorly absorbed compared with human milk fat (Hanna, Navarrete, and Hsu, 1970; Widdowson, 1965), and numerous substitutes for this have been evaluated including destearinated beef fat (oleo oil) and the oils of coconut, soy bean, peanut, safflower, corn, and palm kern, either singly or in various mixtures (Fomon, 1967). Experience with artificial milks containing such fat mixtures has allowed some of the factors modifying fat absorption from the gut of the term human infant to be identified. Absorption is enhanced with fats containing a high proportion of medium or short chain fatty acids, a high proportion of mono- or polyunsaturated fatty acids, or triglycerides with a low proportion of stearic acid in the 2- position (Holt et al., 1935; Tomarelli et al., 1968). The situation for a particular mixture of fats is therefore complex, and is also modified by the presence of other dietary constituents.

The absorption of fat by the premature or low birthweight infant has not been extensively studied. Though absorption of butterfat and olive oil has been shown to be less in the premature than in the normal infant (Holt et al., 1935; Tidwell et al., 1935), there have been few investigations on the relation between the absorption of these fats and calcium balance in premature infants. In term

Received 17 November 1972. infants increased dietary fat has been related to poor calcium absorption and negative calcium balance (Southgate et al., 1969).

In this paper, the absorption of fat and calcium by low birthweight infants fed with two experimental milk formulae is reported. The formulae differed only in the chemical nature of their fat contents which were butterfat and olive oil, respectively, but the total fat, protein, mineral, and calorie contents of the milk were identical.

\section{Methods}

The infants studied were admitted to the special care baby unit during a period of 22 months. They were selected consecutively as they became available within 3 to 34 days after birth, provided they were not breast fed, had no gastrointestinal disturbance or other symptoms, and parental consent had been given. Each infant was given only the test formula from birth to the metabolic balance. Gestational ages were assessed by the paediatric staff, taking into account clinical evaluation (Dubowitz, Dubowitz, and Goldberg, 1970) and obstetric data.

The experimental design was devised to exclude any secular changes in balance or analytical techniques that might have occurred during the 22 months of this study. The 3 groups of infants were designated groups 1,2 , and 3 , corresponding to the periods 1,2 , and 3 in which they were studied. The infants fed formula A(Butterfat) were studied during two periods (periods 1 and 3), which immediately preceded and followed period 2 in which the infants were fed formula B(Olive Oil).

In order to eliminate any errors in the allocation of 
formulae, all infants in the special care unit during each of the 3 study periods received the same test formula irrespective of whether or not they participated in the metabolic balances.

The balance technique was that described by Widdowson (1965) in which feeds prepared to constant dilution were offered during a 3-day period with carmine markers added to the first and last feeds. The amount taken at each feed was determined by weight to the nearest $0.1 \mathrm{~g}$. Throughout the balance period, stools and regurgitated milk were collected on specially prepared acid-washed nylon napkins and bibs covered with polyethylene sheet. No provision was made to collect urine separately. All specimens were stored at $4^{\circ} \mathrm{C}$ before preparation according to a strict protocol. After manual separation of faecal or regurgitated material, the bibs and napkins were brushed with a nylon brush in warm $1 \% \mathrm{HCl}$, boiled in deionized water, and rinsed twice in cold deionized water. The washings and faeces were combined and homogenized with a Silverson mixer-emulsifier and the volume measured. Aliquots of the prepared milk and the faecal homogenate were obtained, and the total fat and calcium contents of each were determined using the method of van de Kamer, Huinink, and Weyers (1949) and by atomic absorption spectrophotometry, respectively. The mean weight of each infant during the balance period was determined, and the retention of fat and calcium per unit body weight per day was calculated.

The two milks were prepared for this trial by Glaxo Laboratories from a carbohydrate modified cow's milk adjusted to constant fat/protein ratio and incorporating appropriate supplements of vitamins and iron. The formula designated $\mathrm{A}$ (Butterfat) contained butterfat, while in formula $B$ (Olive Oil) the butterfat was replaced by olive oil. The general formulation for the milks is given in Table I. The fatty acid profile for

TABLE I

Composition of milk formulae $100 \mathrm{ml}$

\begin{tabular}{lr}
\hline Fat $(\mathrm{g})^{\star}$ & $2 \cdot 8$ \\
Carbohydrate $(\mathrm{g}) \dagger$ & $9 \cdot 9$ \\
Protein (g) & $1 \cdot 8$ \\
Calcium (mg) & $62 \cdot 4$ \\
Phosphorus (mg) & $52 \cdot 8$ \\
Ca/P & $1 \cdot 2$ \\
\hline
\end{tabular}

$\star$ See Fig. 1 for fatty acid compositions.

†Lactose $52 \%+$ maltodextrins $48 \%$.

each milk was determined after hydrolysis and methylation by gas liquid chromatography on a $20 \%$ diethylene glycol succinate on chromosorb W HMDS 80-100 mesh column by means of a Perkin Elmer F11 dual column system. The major features of the fatty acid content of each milk are given in Fig. 1. The principal differences lie in the high oleic acid (18:1) of $\mathrm{B}$ (Olive Oil) $(78.0 \%)$ compared with $35.3 \%$ in A(Butterfat), and the palmitic acid $(16 \cdot 0)(9 \cdot 7 \%)$ in $\mathrm{B}$ (Olive Oil) compared with $31.6 \%$ in $\mathrm{A}$ (Butterfat).

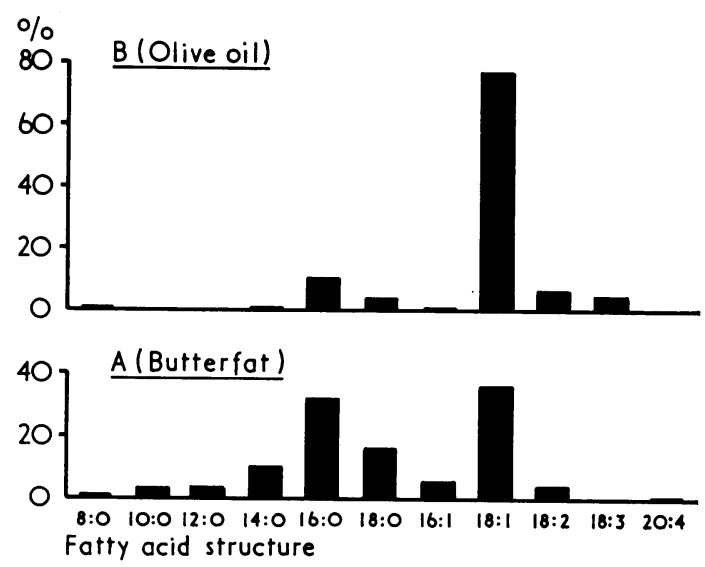

FIG. 1.-Percentage fatty acid composition of milks containing butterfat $(A)$ and olive oil $(B)$ as the principal lipid component.

\section{Findings}

Thirty-three infants of mean age 13.5 (5-35) days and mean gestational age $36 \cdot 3(27-42)$ weeks were studied. Qualitative differences in the nature of the stools were noted such that infants fed with A(Butterfat) produced formed stools of firm consistency, whereas infants fed with $B$ (Olive Oil) produced stools that were soft and semiformed. These differences were associated with a slightly increased mean retention time of the first carmine marker and a decrease in the mean number of stools per day in the $\mathrm{B}$ (Olive Oil) group compared with the A(Butterfat) groups of infants (Table II).

The balance data for individual infants at the time of each balance, together with the actual excretion of fat and calcium, are given in Tables III and IV.

The data from groups 1 and 3 showed no significant difference in the absorption of fat and were combined. The mean fat absorption in infants fed A(Butterfat) was $1.90 \mathrm{~g}$ fat/kg per day compared with $3.38 \mathrm{~g} / \mathrm{kg}$ per day for the $\mathrm{B}$ (Olive Oil) group, and this difference was significant at the 0.001 level (Fig. 2). The calcium data were treated similarly but although the mean value for the combined A(Butterfat) groups was $-3.09 \mathrm{mg} \mathrm{Ca} / \mathrm{kg}$ per day compared with $+0.14 \mathrm{mg} \mathrm{Ca} / \mathrm{kg}$ per day for the $\mathrm{B}$ (Olive Oil) group, the difference was not statistically significant (Fig. 3).

Fat retention for the combined $A$ (Butterfat) data increased with both age and age + gestational age, but the correlation in neither case was significant (Fig. 4, 5). Similar findings were obtained in serial determinations in individual infants. There was no significant correlation between calcium intake and 
TABLE II

Infant mean weights and stool characteristics

\begin{tabular}{|c|c|c|c|c|c|c|}
\hline \multirow{2}{*}{ Period } & \multirow{2}{*}{ Milk } & \multirow{2}{*}{ No. } & \multirow{2}{*}{$\begin{array}{c}\text { Infant weight } \\
(\mathbf{k g} \pm \mathrm{SD})\end{array}$} & \multicolumn{3}{|c|}{ Stools } \\
\hline & & & & Consistency & $\begin{array}{c}\text { Retention } \\
\text { time (hr) }\end{array}$ & $\begin{array}{c}\text { No. } \\
(24 \mathrm{hr})\end{array}$ \\
\hline $\begin{array}{l}1 \\
2 \\
3\end{array}$ & $\begin{array}{l}\text { A(Butterfat) } \\
\text { B(Olive Oil) } \\
\text { A(Butterfat) }\end{array}$ & $\begin{array}{r}13 \\
13 \\
7\end{array}$ & $\begin{array}{l}1 \cdot 62 \pm 0 \cdot 42 \\
2 \cdot 20 \pm 0 \cdot 46 \\
1 \cdot 93 \pm 0 \cdot 34\end{array}$ & $\begin{array}{l}\text { Formed } \\
\text { Soft } \\
\text { Formed }\end{array}$ & $\begin{array}{l}15 \cdot 5 \quad(8-36) \\
17 \cdot 4 \quad(6-62) \\
14 \cdot 7(12-16)\end{array}$ & $\begin{array}{l}5 \cdot 9(3-8) \\
3 \cdot 1(0-6) \\
5 \cdot 3(4-8)\end{array}$ \\
\hline
\end{tabular}

TABLE III

3-day balance data for infants fed A(Butterfat)

\begin{tabular}{|c|c|c|c|c|c|c|}
\hline $\begin{array}{l}\text { Case } \\
\text { no. }\end{array}$ & $\begin{array}{l}\text { Age } \\
(\mathrm{dy})\end{array}$ & $\begin{array}{c}\text { Age }+ \text { gestational } \\
\text { age (wk) }\end{array}$ & $\begin{array}{c}\text { Mean weight } \\
(\mathrm{kg})\end{array}$ & $\begin{array}{l}\text { Milk intake } \\
\quad(\mathrm{ml})\end{array}$ & $\begin{array}{c}\text { Fat excreted } \\
(\mathrm{g})\end{array}$ & $\begin{array}{l}\text { Ca excreted } \\
\text { (mg) }\end{array}$ \\
\hline \multicolumn{2}{|c|}{ 1st period } & & & & & \\
\hline 1 & 16 & 36 & $1 \cdot 15$ & 821 & $13 \cdot 7$ & 570 \\
\hline 2 & 15 & 36 & $2 \cdot 13$ & 1477 & $24 \cdot 7$ & 955 \\
\hline 3 & 36 & 39 & $2 \cdot 23$ & 1437 & $27 \cdot 9$ & 1057 \\
\hline 4 & 13 & 32 & $1 \cdot 30$ & 925 & $16 \cdot 2$ & 557 \\
\hline 5 & 10 & 38 & $2 \cdot 01$ & 1141 & $24 \cdot 3$ & 810 \\
\hline 6 & 19 & $42 \cdot 5$ & $1 \cdot 52$ & 1028 & $21 \cdot 9$ & 826 \\
\hline 7 & 8 & 27 & $0 \cdot 75$ & 494 & $9 \cdot 1$ & 393 \\
\hline 8 & 11 & $34 \cdot 5$ & $1 \cdot 67$ & 1175 & $17 \cdot 9$ & 731 \\
\hline 9 & 22 & 38 & $2 \cdot 11$ & 1498 & $11 \cdot 9$ & 1095 \\
\hline 10 & 6 & 34 & $1 \cdot 62$ & 820 & $16 \cdot 3$ & 600 \\
\hline 11 & 6 & 34 & $1 \cdot 46$ & 783 & $15 \cdot 7$ & 562 \\
\hline 12 & 12 & $37 \cdot 5$ & $1 \cdot 79$ & 1090 & $18 \cdot 3$ & 675 \\
\hline 13 & 5 & $30 \cdot 5$ & $1 \cdot 39$ & 468 & $7 \cdot 5$ & 186 \\
\hline \multicolumn{2}{|c|}{ 3rd period } & & & & & \\
\hline 27 & 5 & $37 \cdot 5$ & $1 \cdot 93$ & 762 & $5 \cdot 1$ & 490 \\
\hline 28 & 13 & 36 & $2 \cdot 48$ & 1266 & $16 \cdot 6$ & 825 \\
\hline 29 & 21 & 35 & $1 \cdot 83$ & 1012 & 13.9 & 566 \\
\hline 30 & 6 & 42 & $2 \cdot 29$ & 1058 & $11 \cdot 6$ & 576 \\
\hline 31 & 6 & 37 & $1 \cdot 92$ & 917 & $13 \cdot 6$ & 456 \\
\hline 32 & 22 & 35 & $1 \cdot 57$ & 959 & $16 \cdot 3$ & 797 \\
\hline 33 & 15 & 34 & $1 \cdot 55$ & 1038 & $13 \cdot 5$ & 508 \\
\hline
\end{tabular}

TABLE IV

3-day balance data for infants fed B(Olive Oil)

\begin{tabular}{|c|c|c|c|c|c|c|}
\hline $\begin{array}{l}\text { Case } \\
\text { no. }\end{array}$ & $\begin{array}{l}\text { Age } \\
\text { (dy) }\end{array}$ & $\begin{array}{c}\text { Age }+ \text { gestational } \\
\text { age (wk) }\end{array}$ & $\begin{array}{l}\text { Mean weight } \\
(\mathrm{kg})\end{array}$ & $\begin{array}{l}\text { Milk intake } \\
(\mathrm{ml})\end{array}$ & $\begin{array}{c}\text { Fat excreted } \\
(\mathbf{g})\end{array}$ & $\begin{array}{l}\text { Ca excreted } \\
\text { (mg) }\end{array}$ \\
\hline $\begin{array}{l}{ }^{2 n}{ }^{2 n} \\
15 \\
16 \\
17 \\
18 \\
19 \\
20 \\
21 \\
22 \\
23 \\
24 \\
25 \\
26\end{array}$ & $\begin{array}{r}\text { iod } \\
9 \\
14 \\
19 \\
7 \\
11 \\
7 \\
9 \\
7 \\
10 \\
20 \\
19 \\
14 \\
16\end{array}$ & $\begin{array}{l}39 \\
33 \\
39 \cdot 5 \\
37 \\
38 \cdot 5 \\
39 \\
36 \\
39 \\
38 \cdot 5 \\
36 \\
38 \cdot 5 \\
40 \\
38 \cdot 5\end{array}$ & $\begin{array}{l}1 \cdot 75 \\
1 \cdot 86 \\
2 \cdot 33 \\
2 \cdot 51 \\
2 \cdot 32 \\
3 \cdot 20 \\
1 \cdot 17 \\
2 \cdot 43 \\
2 \cdot 21 \\
2 \cdot 31 \\
2 \cdot 17 \\
2 \cdot 01 \\
2 \cdot 28\end{array}$ & $\begin{array}{r}891 \\
1130 \\
1321 \\
852 \\
1315 \\
1971 \\
1014 \\
1185 \\
1087 \\
1351 \\
1488 \\
1290 \\
1664\end{array}$ & $\begin{array}{r}10 \cdot 8 \\
14 \cdot 0 \\
1 \cdot 8 \\
2 \cdot 8 \\
14 \cdot 8 \\
22 \cdot 1 \\
6 \cdot 8 \\
10 \cdot 0 \\
7 \cdot 8 \\
9 \cdot 6 \\
9 \cdot 3 \\
9 \cdot 2 \\
11 \cdot 6\end{array}$ & $\begin{array}{r}630 \\
711 \\
645 \\
255 \\
612 \\
1435 \\
618 \\
894 \\
847 \\
1020 \\
1080 \\
1260 \\
919\end{array}$ \\
\hline
\end{tabular}




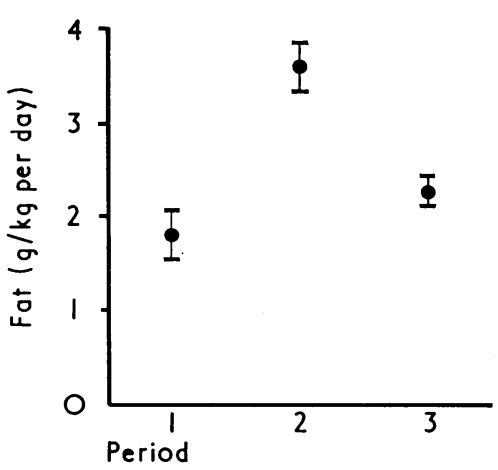

FIG. 2.-Retention of fat by infants receiving milk containing butterfat (periods 1,3 ) and milk containing olive oil (period 2) as principal lipid component (mean \pm SEM).

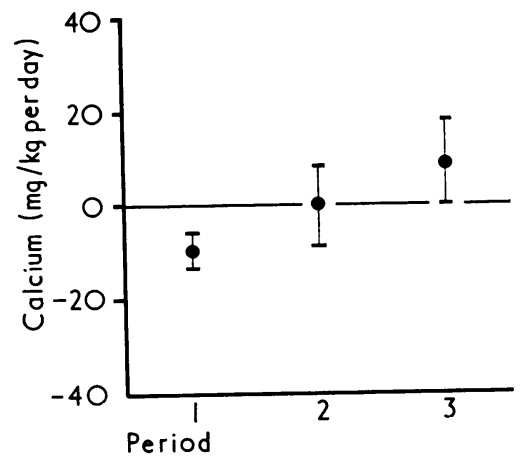

FIG. 3.-Retention of calcium by infants receiving milk containing butterfat (periods 1,3 ) and milk containing olive oil (period 2) as the principal lipid component (mean \pm SEM).

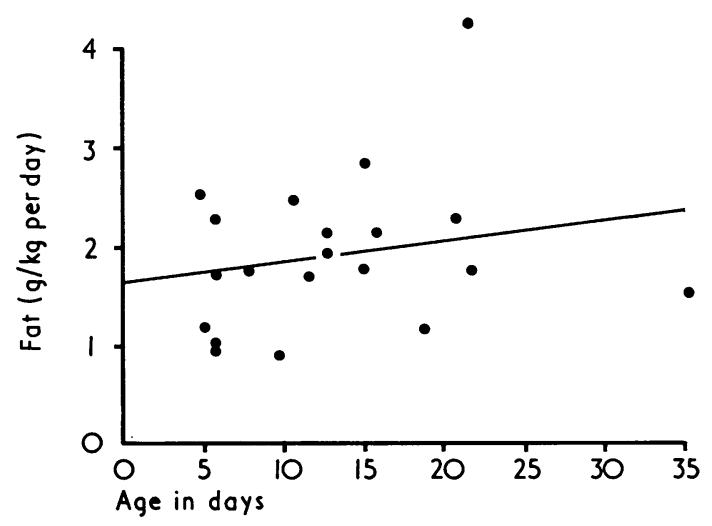

FIG. 4.-Retention of fat by infants fed A(Butterfat) as a function of age with the regression line.

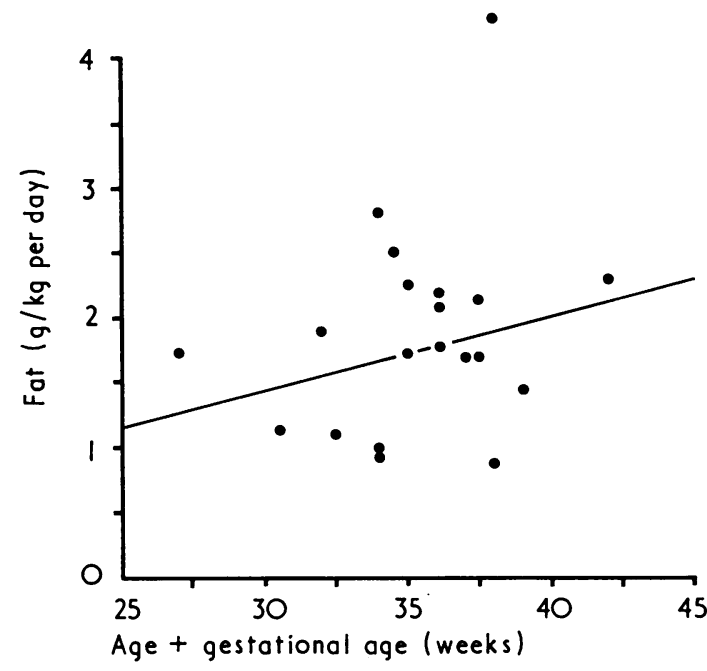

FIG. 5.-Retention of fat by infants fed A(Butterfat) as a function of maturation (age + gestational age) with the regression line.

age or maturity in the groups studied. However, calcium retention tended to increase with age in individual infants in all but one of the infants in whom serial balances were completed, and to become positive 25 to 30 days after birth.

The findings for one infant in whom six balances were completed are illustrated (Fig. 6) and the basic data are given in Table $\mathrm{V}$.

\section{Discussion}

The marked difference in absorption of fat between the two groups of infants indicates that not all fats are equally absorbed by premature infants. The increased absorption of fat from the $B$ (Olive Oil) formula probably reflected both the greater content of oleic acid and the lesser content of stearic acid in that preparation. The mean body weight of infants fed formula $\mathrm{B}$ (Olive Oil) was greater than that of the combined group fed formula $A$ (Butterfat), and it is possible that this could be related to a greater efficiency of fat absorption. This seems to be unlikely in view of the serial balances on one infant (Fig. 6) in which fat absorption per unit body weight was relatively constant in spite of a progressive increase in the total body weight. The increase in calcium absorption in this infant might similarly have been related to the increased body weight. However, it could equally have been related to increasing maturity.

Other factors may also have been operative. The content of polyunsaturates and the proportion of 
TABLE V

Serial 3-day balance data for an infant fed A(Butterfat)

\begin{tabular}{|c|c|c|c|c|c|}
\hline $\begin{array}{l}\text { Age } \\
\text { (dy) }\end{array}$ & $\begin{array}{c}\text { Age }+ \text { gestational } \\
\text { age (wk) }\end{array}$ & $\begin{array}{c}\text { Mean weight } \\
(\mathbf{k g})\end{array}$ & $\begin{array}{l}\text { Milk intake } \\
\quad(\mathrm{ml})\end{array}$ & $\begin{array}{l}\text { Fat excreted } \\
(\mathrm{g})\end{array}$ & $\begin{array}{l}\text { Ca excreted } \\
(\mathrm{mg})\end{array}$ \\
\hline $\begin{array}{l}16 \\
23 \\
30 \\
37 \\
44 \\
51\end{array}$ & $\begin{array}{l}36 \\
37 \\
38 \\
39 \\
40 \\
41\end{array}$ & $\begin{array}{l}1 \cdot 15 \\
1 \cdot 36 \\
1 \cdot 59 \\
1 \cdot 76 \\
1 \cdot 93 \\
2 \cdot 03\end{array}$ & $\begin{array}{r}821 \\
956 \\
1205 \\
1305 \\
1356 \\
1566\end{array}$ & $\begin{array}{l}13 \cdot 7 \\
19 \cdot 0 \\
24 \cdot 2 \\
27 \cdot 0 \\
28 \cdot 1 \\
25 \cdot 9\end{array}$ & $\begin{array}{l}570 \\
631 \\
711 \\
793 \\
723 \\
720\end{array}$ \\
\hline
\end{tabular}

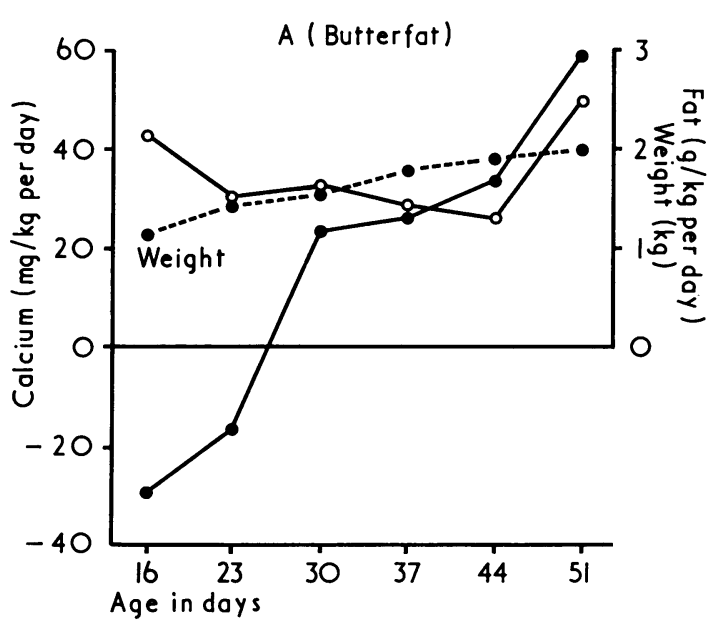

FIG. 6.-Serial determinations of calcium (-) and fat (o-0) retention in a low birthweight infant.

stearic acid in the 2 position in the original triglyceride are known to affect the absorption of fats (Holt et al., 1935; Tomarelli et al., 1968) so that it is difficult to ascribe the observed differences to any one cause. Certainly the findings cannot be generally applied to all fats of vegetable origin since triglyceride structure may vary with respect to the location of fatty acids to particular positions on the triglyceride molecule and their steric configuration (Jensen and Sampugna, 1966).

The apparent lack of a relation between fat and calcium absorption in these infants and in the same infant at different ages is consistent with previously reported studies involving the $\mathrm{A}$ (Butterfat) series of milks (Barltrop and Oppé, 1970). Though it has been suggested that the formation of calcium soaps in the gut may impair the absorption of calcium by term infants, this might only apply under conditions of unusually high intakes of fat compared with the situation in this study. The present findings suggest that under conditions of normal fat intake variations in the efficiency of absorption of fat do not materially affect the contemporaneous absorption of calcium. It is possible that the altered consistency and fat content of faeces induced by the formula containing olive oil compared with that containing butterfat might be associated with a decreased tendency to soap formation in the intestinal lumen, but this seems unlikely.

As fat provides up to $50 \%$ of the total calorie content of most infant formulae, it is important to make allowance for the variations in absorption occurring with different fats. Estimation of caloric intake on the basis of milk composition alone is likely to be misleading when fats of different origins are concerned. Infants in our study who received a butterfat formula utilized only $60 \%$ of the calories from fat compared with those infants receiving milk containing olive oil.

The greater absorption of vegetable oil does not necessarily imply any physiological advantage for the infant. However, the inherent economy might allow the caloric needs of the premature infant to be satisfied by feeds of smaller volume than is necessary with cow's milk.

The milk formulae were developed in collaboration with Dr. W. F. J. Cuthbertson (Glaxo Research Ltd.) and prepared by Glaxo Laboratories Ltd. Miss C. Copland and Mrs. P. Dillon prepared the metabolic balances. Mrs. C. Harford and Mrs. H. Rotholtz made the chemical analyses. D. B. is a Wellcome Senior Fellow in Clinical Science. Part of the costs were defrayed by a grant from the Children's Research Fund.

\section{REFERENCES}

Barltrop, D., and Oppé, T. E. (1970). Dietary factors in neonatal calcium homoeostasis. Lancet, 2, 1333.

Dubowitz, L. M. S., Dubowitz, V., and Goldberg, C. (1970) Clinical assessment of gestational age in the newborn infant. fournal of Pediatrics, 77, 1.

Fomon, S. J. (1967). Infant Nutrition, p. 80. Saunders, Philadelphia.

Hanna, F. M., Navarrete, D. A., and Hsu, F. A. (1970). Calciumfatty acid absorption in term infants fed human milk and prepared formulas simulating human milk. Pediatrics, 45, 216. 
Holt, L. E., Tidwell, H. C., Kirk, C. M., Cross, D. M., and Neale, S. (1935). Studies in fat metabolism. I. Fat absorption in normal infants. Fournal of Pediatrics, 6, 427.

Jensen, R. G., and Sampugna, J. (1966). Triglyceride structure of cow's milk fat. A review. Fournal of Dairy Science, 49, 460.

Southgate, D. A. T., Widdowson, E. M., Smits, B. J., Cooke, W. T., Walker, C. H. M., and Mathers, N. P. (1969). Absorption and excretion of calcium and fat by young infants. Lancet, 1 , 487.

Tidwell, H. C., Holt, L. E., Jr., Farrow, H. L., and Neale, S. (1935). Studies in fat metabolism. II. Fat absorption in premature infants and twins. Fournal of Pediatrics, 6, 481.

Tomarelli, R. M., Meyer, B. J., Weaber, J. R., and Bernhart, F. W. (1968). Effect of positional distribution on the absorption of the fatty acids of human milk and infant formulas. Fournal of Nutrition, 95, 583.

van de Kamer, J. H., Huinink, H. ten B, and Weyers, H. A. (1949). Rapid method for the determination of fat in feces. fournal of Biological Chemistry, 177, 347.

Widdowson, E. M. (1965). Absorption and excretion of fat nitrogen, and minerals from 'filled' milks by babies one week old. Lancet, 2, 1099.

Williams, M. L., Rose, C. S., Morrow, G., Sloan, S. E., and Barness, L. A. (1970). Calcium and fat absorption in neonatal period. American fournal of Clinical Nutrition, 23, 1322.

Correspondence to Dr. D. Barltrop, Paediatric Unit, St. Mary's Hospital Medical School, London W.2. 